\title{
Effect of different saline Levels and Irrigation Regimes on agronomic parameters of potatoes crop under the semi-arid environment of Tunisia
}

ARTICLE · DECEMBER 2015

READS

44

8 AUTHORS, INCLUDING:

\section{Boutheina Douh}

High Agronomic Institute of Chott Mariem 28 PUBLICATIONS 15 CITATIONS

SEE PROFILE

Giovanni Rallo

Università di Pisa

48 PUBLICATIONS 124 CITATIONS

SEE PROFILE

\section{Dario Autovino}

Università degli Studi di Palermo

4 PUBLICATIONS O CITATIONS

SEE PROFILE

\section{Giuseppe Provenzano}

Università degli Studi di Palermo

92 PUBLICATIONS 535 CITATIONS

SEE PROFILE 


\title{
Effect of different saline Levels and Irrigation Regimes on agronomic parameters of potatoes crop under the semi-arid environment of Tunisia
}

\author{
H. Ghazouani ${ }^{1,2}$, B. Latrach ${ }^{1}$, M. Amel ${ }^{3}$, B. Douh ${ }^{1}$, D. Autovino ${ }^{2}$, G. Rallo², G. Provenzano ${ }^{2}$, B. \\ Abdelhamid $^{1}$
}

1. Department of Genius of Horticultural Systems and Environment, Higher Institute of Agronomy, BP 47, Chott Mariem 4042, University of Sousse, Tunisia.

2. Dipartimento Scienze Agrarie e Forestali, Università degli Studi di Palermo, Italy.

3. Regional Field Crops Research Center (CRRGC) Béja Tunisia: B. P. 350 Béja 9000 - Tunisia

Corresponding Author email: boutheina_douh@yahoo.fr

Paper Information
Received: 14 August, 2015
Accepted: 27 octobre, 2015
Published: 20 November, 2015
Citation
Ghazouani H, Latrach B, Amel M, Douh B, Autovino D,
Rallo D, Provenzano G, Abdelhamid B. 2015. Effect of
different saline Levels and Irrigation Regimes on
agronomic parameters of potatoes crop under the semi-arid
environment of Tunisia. Scientia Agriculturae, 12 (2), 99-
104. Retrieved from ww.pscipub.com (DOI:
10.15192/PSCP.SA.2015.12.2.99104)

\begin{abstract}
A B S T R A C T
In Tunisia, the scarcity of water for irrigation allows the use of low water quality. Deficit irrigation has shown successful results with a large number of crops in various countries. Field experiments, were carried out in Central Tunsia $\left(10.5632^{\circ} \mathrm{W} ; 35.9191^{\circ} \mathrm{N} ; 19 \mathrm{~m}\right.$ a.s.l) on a potatoes crop planted in a sandy loam soil, during the growing season 2015, from January 21 (plantation of tubers) to May 21 (harvesting). Objective of the work, was to assess four different irrigation management on the agronomic parameters of potatoes crop and Water use efficient. The experimental field were laid out in a randomized complete block design consisting of two different irrigation levels and two water qualities. Each plot received the same plant management and was irrigated by a subsurface drip irrigation system (SDI). The first plot irrigated with water characterized by electrical conductivity of $1.0 \mathrm{dS} / \mathrm{m}$ T1 with $100 \%$ ET0, T2 with $50 \%$ ET0, the second plot was irrigated with water with a water of $4 \mathrm{dS} / \mathrm{m}$ and was compound by T3 with $100 \%$ ET0 and T4 with $50 \%$ ET0. This study was aimed to investigate on the effect of salt stress or water stress and the combination salt water stress on some agronomics parameters of potatoes. Statistical analysis evidenced that the degree of salinity has a highly significant positive effect on the plant's growth, leaf area, tuber yield and volume efficiency, and water use efficiency.

(C) 2015 PSCI Publisher All rights reserved.
\end{abstract}

Key words: Evapotranspiration; salt stress; subsurface drip irrigation; water stress; water use efficiency

\section{Introduction}

One of the worldwide problems facing irrigated agriculture is water scarcity. In many arid countries, especially with the climate change and the increases of the urban and industrial needs, water is being more and more scarce. Since, it is recommended for the next century to adopt new strategies aiming to better manage the available water resources. In the prevailing semi arid environment of Tunisia, irrigated agriculture uses about $83 \%$ of the total water resources. The national water policies subsidize the drip installation equipment in order to improve the water use efficiency. Since, the cost of installation relatively decreased and the irrigated areas with drip irrigation system have been expanded leading to a contribution of about $35 \%$ of the total agriculture production. Potato crop is one of the important widespread food crops amongst the world, and is considered as a relatively sensitive crop to water and salt stress FAO(1985) particularly in the early growth stages (Levy, 1992; Nadler and Heuer, 1995).. However the effect of water stress and salinity on the tuber yield depends on the cultivar (Zhang et al., 1993). Gupta and Abrol, 1990 and FAO, 1995 showed that under arid conditions, even when irrigating with good water quality, irrigation projects leads to salinity problems .However, several problems related to salt effect could be avoided when irrigating with subsurface drip irrigation such as the (1) contact saltplant, especially for salt sensitive plant tissues and (2) the important losses by evaporation (emitters are laid on a certain depth) (Pateal R.M. et al, 2001). Even with this advantage, only some studies used subsurface drip irrigation with saline water under arid or semi-arid environment. Moreover, the effect of the saline and water stress on the agronomic parameters of potatoes crops for the Tunisian environment has not been reported in the literature (Elmokh et al., 2015).

This study was considered under semi arid environment of the central Tunisia in order to investigate on the effect of salt stress, water stress and the combined salt water stress on some vegetative parameters of potatoes like highest of the 
canopy, leaf area root density and others production parameters such as total yield, volume and percentage of dry matter on tubers.

\section{Materiel and methods \\ Experimental activities}

trials were conducted at the experimental field of the high agronomic institute of Chott Mariem, Sousse, Tunisia (Long. $10.5632^{\circ} \mathrm{N}$; Lat. $35.9191^{\circ} \mathrm{N}$, Altitude $19 \mathrm{~m}$ above sea level). Annual precipitation is about $230 \mathrm{~mm}$ concentrated between December and Mars. The spring and early summer season are normally quite dry. The dominant soil is sandy loam (clay $=8 \%$, silt $=31 \%$ and sand $=61 \%$ ) with an average bulk density of $1.6 \mathrm{~g} \cdot \mathrm{cm}^{-3}$ for a layer thickness of $80 \mathrm{~cm}$. Basic seed tubers of Potato crop 'Solanum Tubersum L.', cultivar Spunta were planted with a distance of $40 \mathrm{~cm}$ along the row and $80 \mathrm{~cm}$ between the row.

The experimental field were laid out in a randomized complete block design consisting of two different irrigation levels and two water qualities. Each plot received the same plant management and was irrigated by a subsurface drip irrigation system (SDI). SDI lateral lines were installed $25 \mathrm{~cm}$ bellow the soil surface. The dripper was inline type and placed $0.4 \mathrm{~m}$ from each other and delivered $41 / \mathrm{h}$ flow rate at $1.0 \mathrm{~atm}$ pressure. Counters were placed in order to determine the exact water depth that has been provided for the plant. The first plot irrigated with water characterized by electrical conductivity of $1.0 \mathrm{dS} / \mathrm{m}$ T1 with $100 \%$ ET0, T2 with $50 \%$ ET0, the second plot was irrigated with water with a water of $4 \mathrm{dS} / \mathrm{m}$ and was compound by T3 with $100 \%$ ET0 and T4 with $50 \%$ ET0.

The water amounts of the other treatment were calculated by using a percentage of deficit (50\%) according to the water amount provided for (T1) treatment. Five drip lines for each plot were in the experiments. N, P, K fertilizers were applied uniformly for both the treatment three times during the whole cycle. To improve water uniformity, a series of valve were placed in the end of each line. For the whole growth season, leaf area (LA) was determined based on the plant leaves collected from three crops in three different positions inside each plot, by using a Skye leaf v2 system (Skye instruments LTD, Powys, UK), preliminarily calibrated. Leaf samples were taken three times during each vegetative growth stage. Potato crop were planted on 21 January and emerged about four weeks later. They were harvested on 21 May. Root density was observed between 30 and $50 \mathrm{~cm}$ for both the treatment. Crop Yield, tuber size volume and weight were determined in harvesting on the base of 9 randomized plants chosen from in each treatment.

Water use efficiency (WUE) has been calculated as one of the key component, allowing to maximize the yield per unit of water more than unit of land and to evaluate how to produce more with less water (Fereres et Soriano, 2007). WUE, generally calculated as the ratio between the crop yield, Y, and the seasonal values of water supply (1983):

IWUE $=\frac{Y}{I}$

WUE is expressed in $\mathrm{Kg} / \mathrm{m}^{3}$ and $Y \mathrm{i} \quad I$ in $\mathrm{m}^{3}$.

\section{Statistical Analysis}

All the collected data in this study were subjected to the analysis of variance (ANOVA) from the Statistical Analysis System (SPSS 17.0 for Windows) appropriate for the experimental complete block design to evaluate the effect of water and salt stress on the agronomic parameters of potato crop. Means were compared by the S-N-K test at the carried out using the least significant difference (LSD) at 5\% probability level. The mean values of each treatment are designated by letters $(a, b)$ which represent the significance degree of the difference between the means. The letter "a" means the highest average, " $b$ " the following one and c, if exist, the lowest.

\section{Results And Discussion \\ Height of the canopy}

The average height in $\mathrm{cm}$ for the elaborated treatment T1, T2, T3 and T4 are presented in figure (1). Statistical analysis has given a significant effect for treatment T3. However, no significant difference was obtained between Treatment T1, T2 and T4. This means that the SNK test showed a highly significant effect of irrigation regime and water salinity on plant's height. Two treatment groups were classified, one including T3 (a) and the other T1, T2 and T4 (b). The average highest value $47 \pm 8.7 \mathrm{~cm}$ was obtained under treatment T3 and the lowest one $31.67 \pm 9.96 \mathrm{~cm}$ was obtained under treatment T4. It could be deduced, then, that when providing $100 \% \mathrm{ETp}$ with saline water, plant height was improved. (Harer et Nadler (1998)) proved in a past study that moderate saline water may improve the plant height of potato crop. According to Munns (2005), the time scale over which plant was subject to saline stress determines the plant response to saline stress. Two phases are described: the first one is a quicker processes which is related to an osmotic effect, whereas, the second one is related to a various of factors such as plant growth stage, genetic characters , temperature, relative humidity and light intensity. 


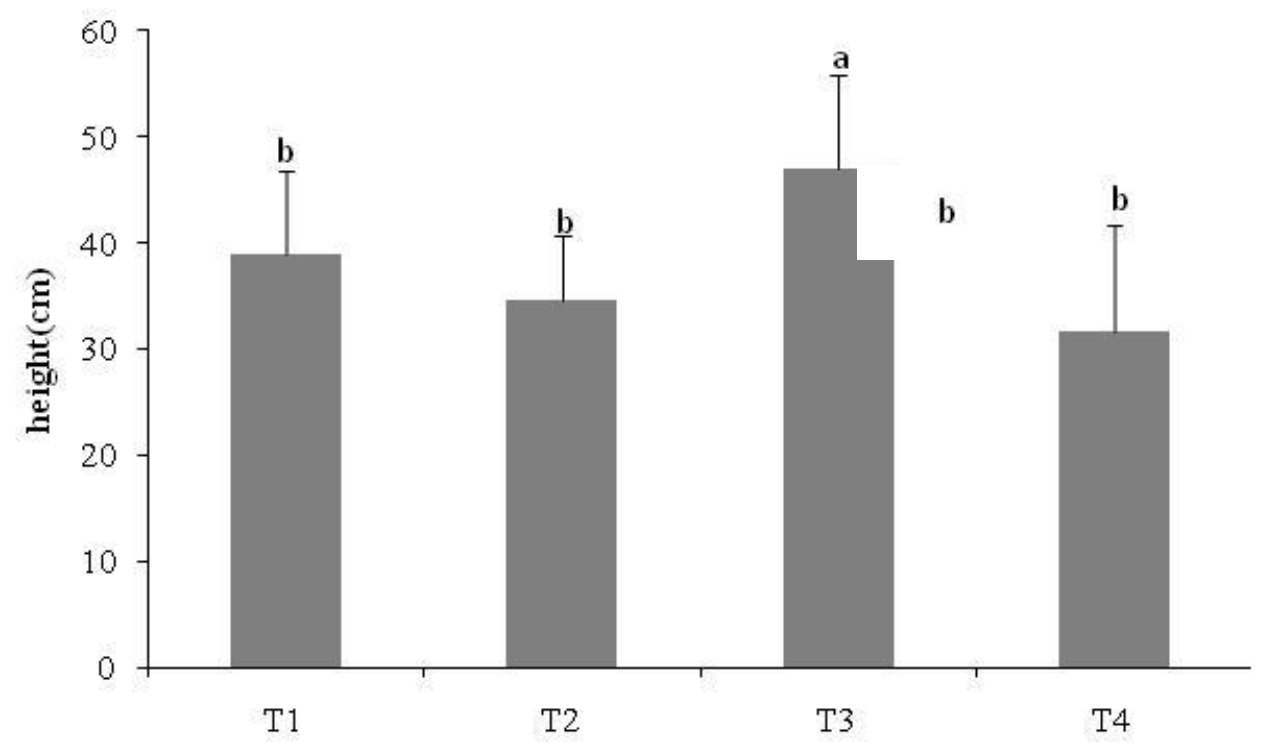

Figure 1. Average height of the canopy and corresponding standard for the elaborated treatments.

\section{Plant's Leaf Area}

Canopy leaf areas were measured at the successive phonological stage on three plants from treatment T1, T2, T3 and T4: the first sampling was taken during the initial stage, the second one during the intermediary stage and the third one was during the final stage (figure2). It is noticeable from that figure that the highest values of leaf area were recorded under irrigation supply of $100 \%$ ET0 and saline water. The highest average leaf area was recorded under T3 is $1741 \pm$ $89.02 \mathrm{~cm}^{2}$. Leaf area does not exceed $975 \pm 84 \mathrm{~cm}^{2}, 805 \pm 98.32 \mathrm{~cm}^{2}, 1128 \pm 178 \mathrm{~cm}^{2}$ respectively for T1, T2 and T4. The SNK test showed a highly significant effect of irrigation regime and water salinity on the leaf area of the plant during the growing season. In the initial stage, SNK test allowed to classify the leaf area into three groups, one including T3 (a) the second comprising $\mathrm{T} 1$ (b) and the third $\mathrm{T} 2$ and $\mathrm{T} 4$ (c). In the intermediary stage, leaf samples were classified into three groups T3 (a), T4 (b) and T1 and T2(c). By the end of the cycle, only two groups were obtained: one including T3 (a) and the other comprising T1, T2, and T4 (b).These results showed that a moderate low water quality for the potato crop may allow an improvement in terms of the leaf area. This result could be explained by the fact that plant could positively adjust the osmotic potentials. Harer et Nadler (1998) investigated on the physiological response of potatoes as affected by salinity or water deficit and reported that a positive turgeor was maintained, even if increasing the water and stress rate. This behavior is mainly achieved by the accumulation of chloride and proline under salt stress condition and, while by altering cell wall elasticity or cell size under water deficit.

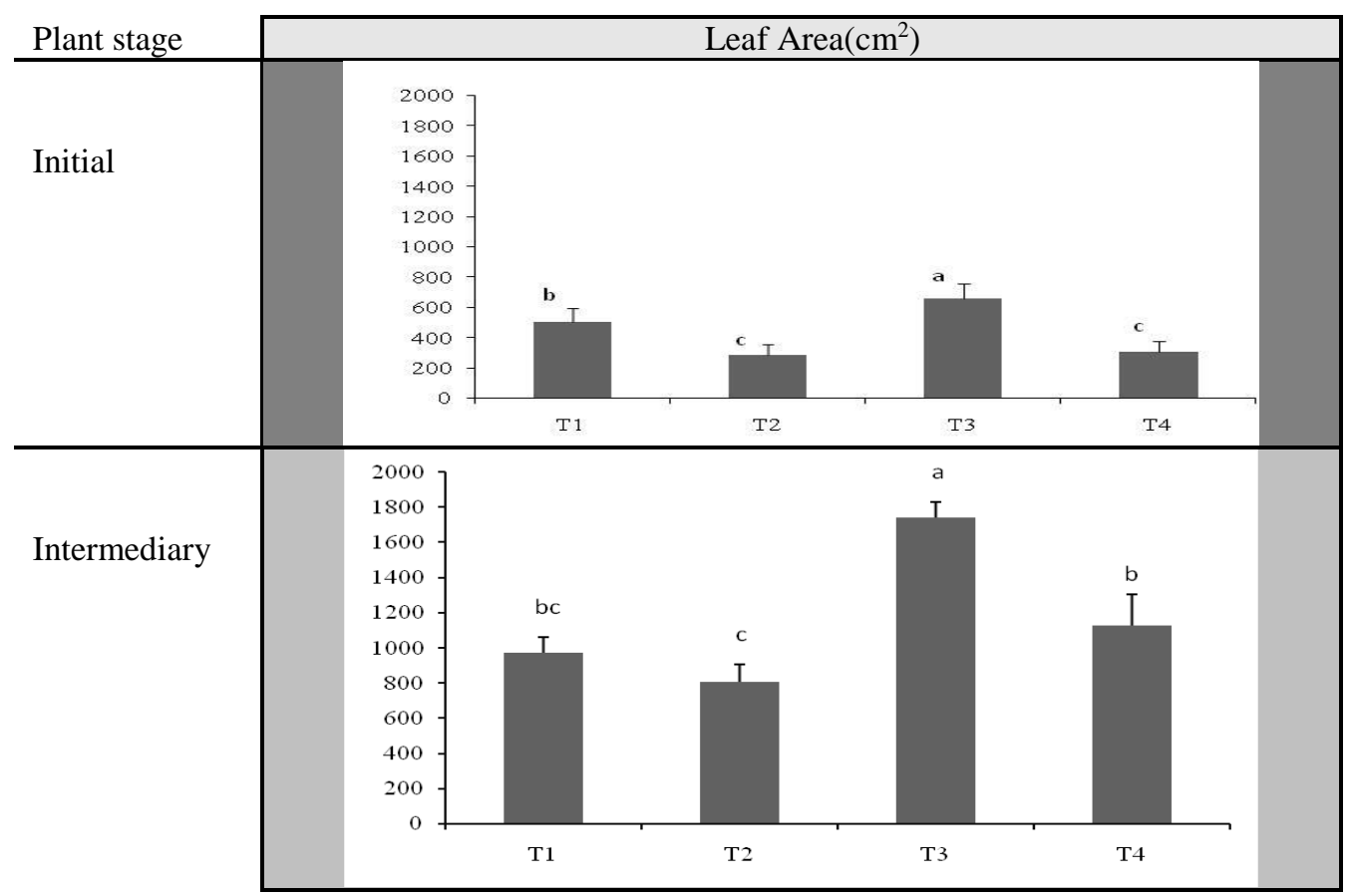




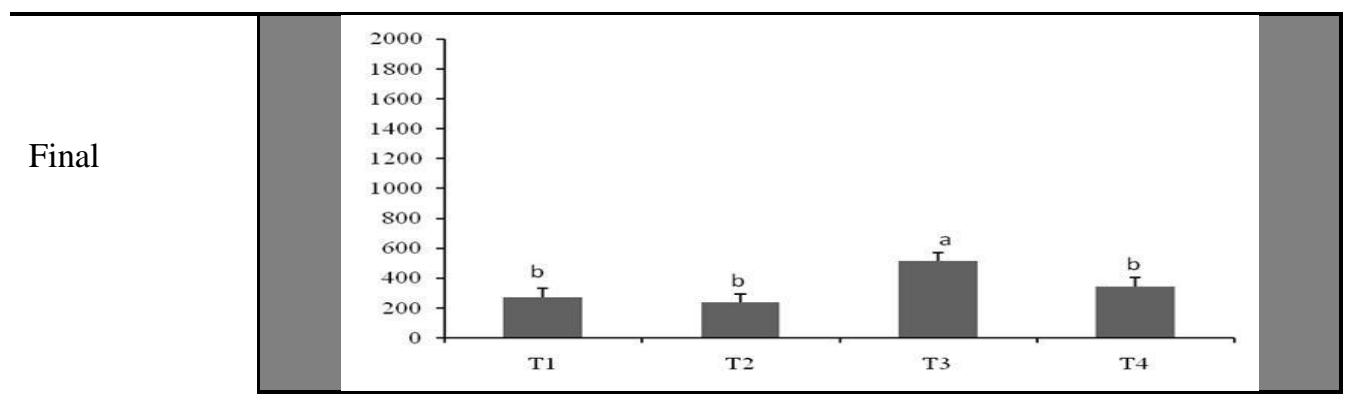

Figure 2. Canopy leaf area taken during three growth stages and the corresponding standard deviations for the elaborated treatment.

\section{Number Of Tubercle}

Figure (3) showed the average tuber number per plant for treatments T1, T2, T3 and T4. Statistical analysis has not given a significant difference between the elaborated treatments. It is therefore recognized, that irrigation regime and salt water didn't affect the number of tubercles per plant. The average tuber number was about $7 \pm 2$ tubers. These results are consistent with the ones found by Dwyer and Boisvert (1990), who concluded that there are no differences on tuber initiation or bulking period between irrigated and non irrigated potatoes. Moreover, according to Gregory (1956) and Slater (1968), tuberization process of potato is mainly controlled by environmental factors, like photoperiod and temperature, which influence the levels of endogenous growth substances.

http://cipotato.org/wp-content/uploads/2014/07/006162.pdf

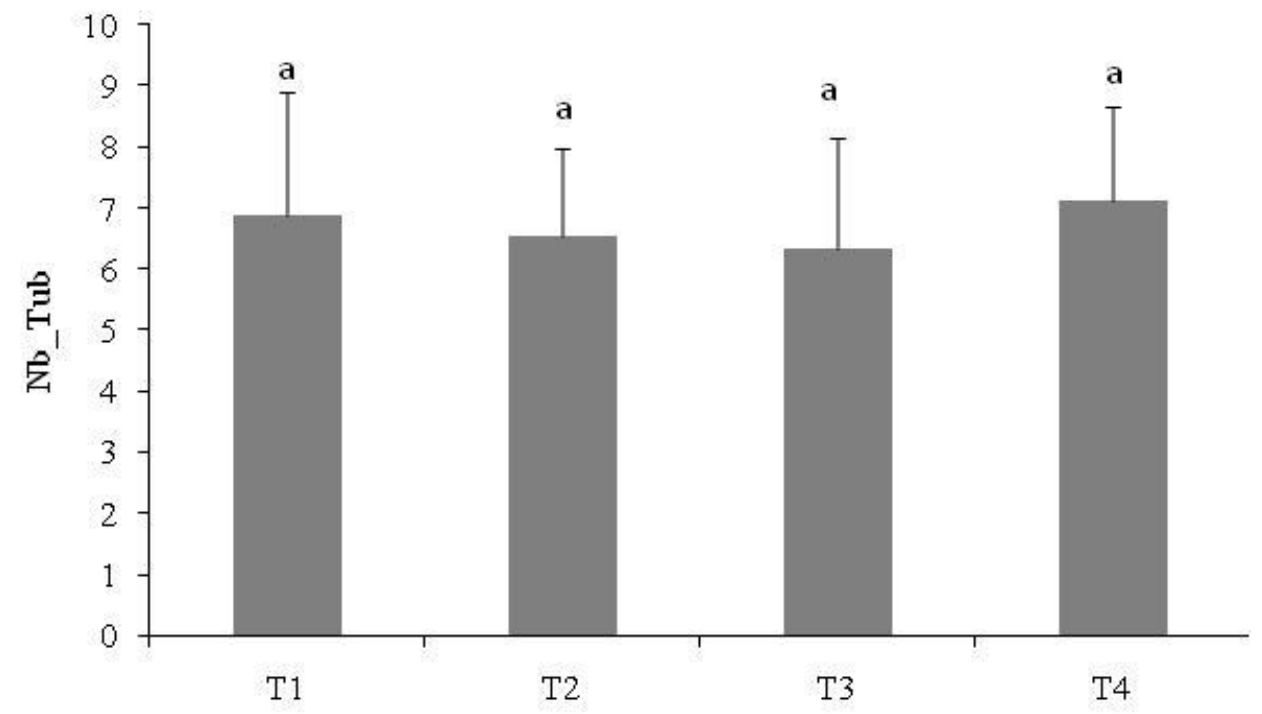

Figure 3. Average Number of Tubercles per plant

\section{Volume, Dry Matter And Weight}

The average tuber volume of potato crop is almost equal to $118.29 \pm 48.52 ; 61.28 \pm 8.37 ; 206.83 \pm 23.41$ and 98.96 $\pm 30.25 \mathrm{~cm}^{3} /$ plant(figure 4 -a), the average values of dry matter are in the order of $22,2 \pm 1.7 ; 21.9 \pm 0.9 ; 22.8 \pm 1.0$ and $22.3 \pm 0.9 \%$ (figure 4-b), and the average tuber weight are equal to $888,18 \pm 185.80 ; 520.31 \pm 76.39 ; 1248.01 \pm 303.49$ and $840.22 \pm 132.69 \mathrm{~g}$, respectively, for the treatments T1, T2, T3 and T4 (figure 4-c). The SNK test showed a highly significant effect of dose and water salinity on the volumes of tubercle and were classified into three groups, one including T3 (a), one comprising T1 and T4 (b) and the last one including T2(c). The same test applied on weight of tubercles showed the same number of homogenous groups that were obtained by analyzing the volume of tubers. Indeed, three groups were obtained, T3 (a), T1 and T3 (b) and T2(c). Dry matter didn't show a significant effect of irrigation dose and saline water. However, the highest dry matter values, in average, were obtained under saline treatment. These results could be explained, by the slight accumulation of chloride and proline in order to maintain a positive turgeor.

http://link.springer.com/article/10.1007\%2FBF02358078

Results in terms of tuber volumes and yield are in harmony with the ones found by Gaddala et al.(2007). Indeed, according to their study, the total yield increased by increasing water salinity up to $6 \mathrm{dS} / \mathrm{m}$ and presented the similar trend of the one obtained when organic addition were provided. Irrigation by salt water with $50 \%$ of ET0 provides the same performance of $\mathrm{T} 1$, and better than the $\mathrm{T} 2$ because irrigation with a saline and 50\% ET0 allows tolerable intake salts when the plant needs less energy to extract water. Moreover, Patel et al. (2001) reported that, the salt sensitivity of potatoes crop affect yield, especially at an early growth season. However, on the Mediterranean climate of Tunisia, rain events occurred 
from January till mid march, so it coincides with the initiation phase of crop cycle. Moreover, Patel et al. (1997) reported that it is possible to produce successfully potatoes crops with low water quality, even having salinities up $9 \mathrm{dS} / \mathrm{m}$ or more, especially when using subsurface drip irrigation system.

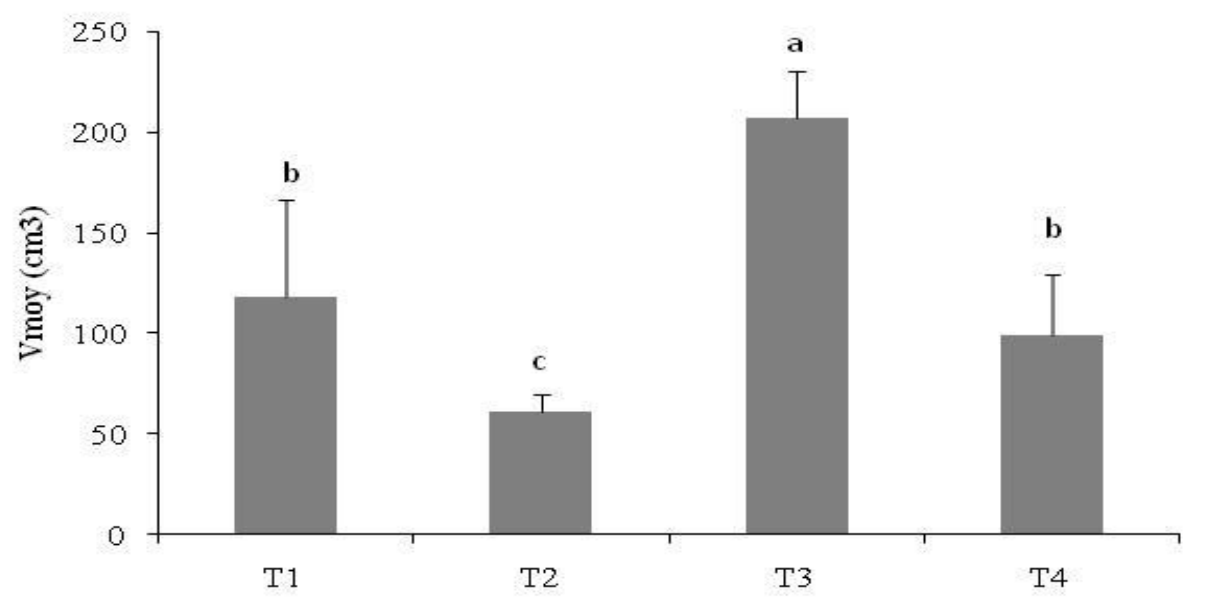

a
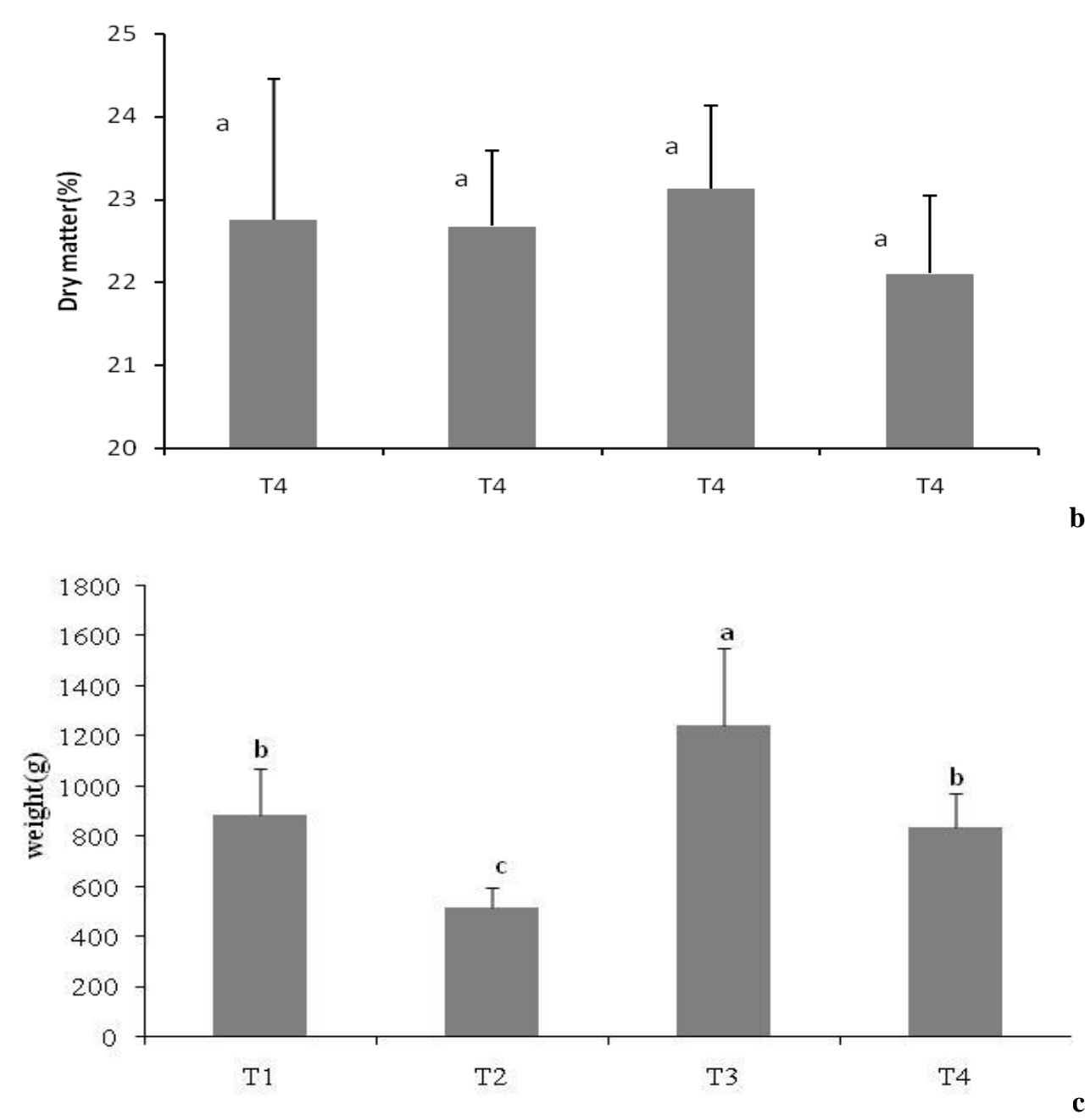

\section{Water Use Effeciency}

Water use efficiencies as affected by irrigation dose and water salinity for treatments T1, T2, T3 and T4 are presented in figure 5. SNK has given a significant difference between the treatments. Three treatment groups are classified. One including T1, T3 (b), the other T2 (a) and the second including T4 (a). In general WUE was higher when irrigating with saline water. Analyzing that figure, it is noticeable that T4 $(50 \%$ Etp and Ec=4 dS/m) was the best in terms of water 
use efficiency $\left(32.31 \mathrm{Kg} / \mathrm{m}^{3}\right)$. That result is in agreement with the one found by Katerji et al. (2003) who analyzed the consequences of different water salinities on the water use efficiency of 10 species. According to that study, two plant groups are classified: the first one is formed by the salt tolerant species, which maintain or improve their water use efficiency under salt condition and the second one includes the plants that are salt sensitive and of which water use efficiency decline with increasing soil salinity. Based on the same study, Potato crop belongs to the first group. However, few studies have been investigated on the effect of water salinity on WUE in the Mediterranean area. These results could also be explained based on the fact that the plant uses the micro element of salt water as nutriment, especially when the salinity is not very high $(4 \mathrm{dS} / \mathrm{cm})$. In fact, the chemical analysis of the saline irrigation water showed relatively low values of bicarbonate $\mathrm{HCO}_{3}{ }^{-}$and an absence of carbonate $\mathrm{HCO}_{3}{ }^{2-}$, which means that some cation like $\mathrm{Mg}^{2+}$ and $\mathrm{Ca}^{2+}$ will be more available for the plant. Moreover, some ion like nitrate and phosphorus are more concentrated on the saline water, which could improve the plant yield. With reducing the quantity of the applied water by the half, an increase of WUE was observed, when passing from $\mathrm{T} 3$ to $\mathrm{T} 4$.

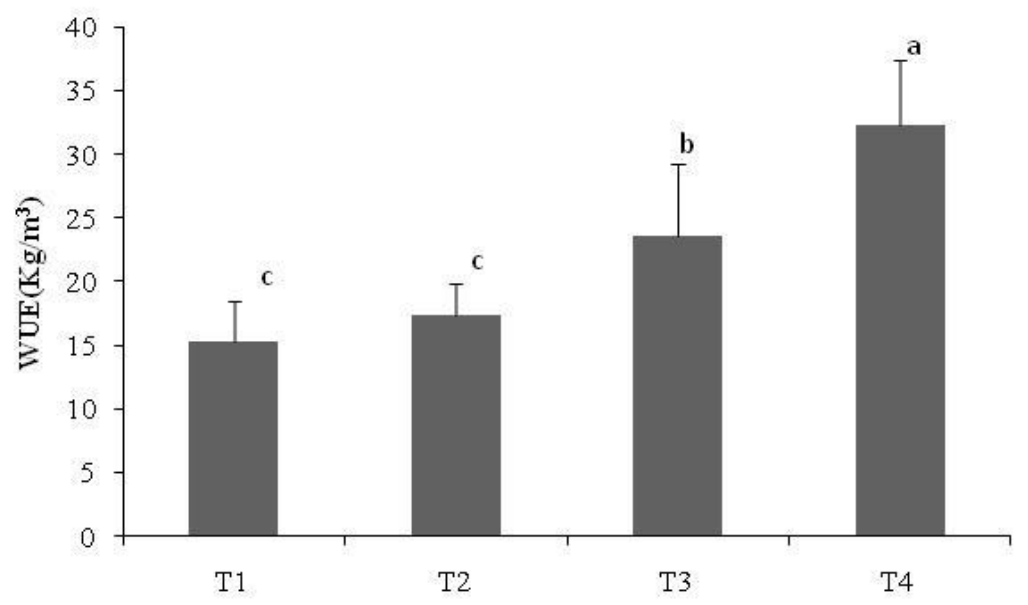

Figure 5. Water use efficiency for treatments T1, T2 T3 and T4

\section{Conclusion}

The objective of this study was to investigate on the effect of salt stress or water stress and the combined salt water stress on some vegetative parameters of potatoes like plant's growth, leaf area, root density, total yield, tuber volume, percentage of dry matter and water use efficiency. Statistical results evidenced that treatment T3 irrigated with $100 \%$ ETp and saline water has given the best results on terms of average plant height, leaf area $\left(1741 \pm 89.02 \mathrm{~cm}^{2}\right.$.), tuber yield $\left(1248.01 \pm 303.49\right.$ and volumes $\left(206.83 \pm 23.41 \mathrm{~cm}^{3}\right)$. However, neither irrigation dose nor water salinity affected the number of tuber and the average dry matter per plant. In term of water use efficiency, T4 showed the highest value $32.31 \pm$ $0.13 \mathrm{Kg} / \mathrm{m}^{3}$.

\section{References}

El Mokh F, Nagaz K, Masmoudi MM, Mechlia NB. 2015. Yield and water productivity of drip-Irrigated potato under different nitrogen levels and irrigation regime with Saline water in arid Tunisia. American Journal of Plant Sciences, 6, 501-510.

FAO. 1985. Water quality for agriculture. Irrigation and Drainage Papers No. 29, Rev.1, FAO, Rome, 143 pp.

FAO. 1995. Potatoes in the 1990s. Situations and Prospects of World Potato Economy. Publ. No. M-71, FAO, Rome, 39 pp.

Fereres E, Soriano MA. 2007. Deficit irrigation for reducing agricultural water use. Journal of experimental botanic. . 58, 147-159.

Gadalla AM, Hamdy A, Galal YGM.2007. Use of saline irrigation water for production of some legumes and tuber plants. In : Lamaddalena N. (ed.), Bogliotti C. (ed.), Todorovic M. (ed.), Scardigno A. (ed.). Water saving in Mediterranean agriculture and future research needs [Vol.2]. Bari: CIHEAM, 2007. p. 85-97 (Options Méditerranéennes : Série B. Etudes et Recherches; n. 56 Vol.II).

Gregory L. 1956. Some factors for tuberization in the potato plant. Journal of botany. 43. 381-388.

Gupta RK. Abrol IP. 1990. Salt-affected soils: their reclamation and management for crop production. In: Lal, R., Stewart, B.A. (Ed.), Advances in Soil Science. Soil Degradation. Springer .11. 223-288.

Katerji N. 2003. Les recherches de l'INRA sur la thématique gestion de l'eau. Séminaire IRD : Eau environnement et développement durable en zone semi-aride. Marrakech.23-25/6/2003. 3P.

Levy D. 1992. The response of potatoes (Solanum tuberosum L.) to salinity: plant growth and tuber yields in the arid desert of Israel. Annals of applied Biolgy. 120 (3). 547-555.

Nadler A, Heuer B. 1995. Effect of saline irrigation and water deficit on tuber quality. Potato Research. 38. 119-123.

Nadler A, Heuer B. 1998. Physiological response of potato plants to soil salinity and water deficit. Plant Science. 43-51.

Patel RM. 1997. Subirrigation with brackish water. Ph.D. thesis, McGill University, Montreal, Canada.

Patela RM, Prashera SO, Donnellyb D, Bonnella RB. 2001.Effect of initial soil salinity and subirrigation water salinity on potato tuber yield and size .Agriculter Water Manage ment.46. 231-239

Slater JW. 1968. The effect of night temperature on tuber initiation of the potato. European potato Journal. 2. 14-22

Zhang Y, Brault M, Chalavi V, Donnelly D. 1993. In vitro screening for salinity tolerant potato. In: Proceedings of the 13th International Congress on Biometeorology. Calgary, Canada. 